\title{
Sophia na Grécia, evocando Fernando Pessoa
}

\section{Sophia in Greece: Evoking Fernando Pessoa}

\author{
Maria António Hörster \\ Universidade de Coimbra, Coimbra / Portugal \\ mahorster@sapo.pt \\ Maria de Fátima Silva \\ Universidade de Coimbra, Coimbra / Portugal \\ fanp13@gmail.com
}

Resumo: Este artigo foca-se na análise de dois poemas de Sophia de Mello Breyner Andresen - "Em Hydra" e "Cíclades" -, um e outro partindo de uma vivência da Grécia insular, sugestiva de uma evocação de Fernando Pessoa. Estes são poemas que exprimem um "diálogo" interessante entre dois poetas paradigmáticos da contemporaneidade portuguesa.

Palavras-chave: Sophia de Mello; Grécia; luz; paisagem; cultura; Fernando Pessoa; poeta de Lisboa.

Abstract: This article analyzes two poems by Sophia de Mello Breyner Andresen, 'In Hydra' and 'Cyclades', both of them inspired by an experience on the Greek islands and evoking the works of Fernando Pessoa. Therefore, these poems express an interesting dialogue between two paradigmatic poets of Portuguese contemporaneity.

Keywords: Sophia de Mello; Greece; light; landscape; culture; Fernando Pessoa; poet of Lisbon. 
Recebido em: 20 de março de 2017.

Aprovado em: 30 de junho de 2017.

\section{Introdução}

\subsection{Notas biobliográficas}

Oriunda de uma família com antecedentes dinamarqueses, pelo lado paterno, e portugueses e belgas, pela via materna, Sophia de Mello Breyner Andresen (1919-2004) nasceu na cidade do Porto, onde passou a infância e a adolescência. Decisivos para a sua obra, sobretudo na fase inicial, seriam o seu contacto com a natureza no reino encantado da quinta da família, ao Campo Alegre, bem como a experiência do mar, na vizinha praia da Granja. Esta contemplação e, mesmo, esta imersão no real circundante, fê-la aceder às vivências opostas do caos e da harmonia $^{1}$ que tão relevantes se mostrariam ao longo de toda a sua obra. ${ }^{2}$

${ }^{1}$ Numa entrevista a Maria Armanda Passos (1982, p. 2), Sophia recorda algumas das
suas primeiras grandes impressões de menina, por exemplo a experiência de grandes
trovoadas durante as quais uma governanta recitava a Magnífica: "E ao mesmo tempo
as palavras da Magnífica criavam uma espécie de salvação e de esplendor no meio do
temporal, no meio do caos".
${ }^{2}$ São numerosos, no seu primeiro livro, poemas que tematizam a harmonia, por exemplo,
"É esta a hora", Dia do mar (cf. Obra poética, p. 132); "As rosas", Dia do mar (cf. Obra poética, p. 133); "Os deuses", Dia do mar (cf. Obra poética, p. 144); ou o caos, "A ti eu canto", Dia do Mar, "Noite", Poesia I (cf. Obra poética, p. 62); Dia do mar (cf. Obra poética, p. 174); "Porque foram quebrados os teus gestos?", Dia do mar (cf. Obra poética, p. 177); ou ambos, por exemplo, "Floresta", Dia do mar (cf. Obra poética, p. 178). Como paradigmas de um e outro polo comparecem por vezes Apolo e Dioniso, por exemplo, "Deus puro, Apolo Musageta", Dia do mar (cf. Obra poética, p. 154); "A ti eu canto", Dia do mar. Registe-se que "A ti eu canto", à semelhança do que sucede com "Dionysos e Apolo", de Poesia I, p. 25-28, poemas em que a dimensão do caos e o louvor de Dioniso são tematizados com maior evidência, que se encontram ausentes da colectânea Obra poética. Sobre a importância que para ela assumia o caos, veja-se a entrevista a Maria Armanda Passos, acima referida, na qual se encontram as seguintes palavras: "Houve um dia um tremor de terra em Delfos e as pedras rolaram do cimo das montanhas e destruíram o templo cá em baixo, na encosta. Não me lembro já quem via neste facto um símbolo de como o caos, manifestando-se através de um tremor de 
Para além disso, muito cedo, mesmo antes de saber ler ainda, contactou com a poesia ${ }^{3}$ tendo interiorizado a melodia, a verdade e a dignidade da linguagem poética.

Dessa fase de formação há ainda a valorizar, dentro da vertente poética que sobretudo nos interessa neste estudo, o encantamento com a Grécia, que viria a ter oportunidades diversas de se apurar, e a levaria a enveredar pelo curso de Filologia Clássica, na Universidade de Lisboa (1936-1939), ainda que não concluído com a obtenção de um grau.

Nome destacado nas letras portuguesas dos séculos XX e XXI, agraciada com o prestigiado prémio Camões em 1999, é como poeta que Sophia se estreia, tendo começado por publicar na primeira série da revista Cadernos de poesia (1940-1942). Incentivada por amigos e apoiada pelo conselho de Miguel Torga, viria a lançar a sua primeira colectânea, Poesia (1944), em edição de Autora. Seguem-se numerosos volumes líricos como Dia do mar (1947), Coral (1950), No tempo dividido (1954), Mar novo (1958), O Cristo cigano (1961), Livro sexto (1962), Geografia (1967), Grades (1970), Dual (1972), O nome das coisas (1977), Navegações (1983), Ilhas (1989), Musa (1994), O búzio de cós (1997), Orpheu e Eurydice (2001). Do seu trajecto literário fazem também parte colectâneas de contos, com destaque para Contos exemplares (1962) e Histórias da terra e do mar (1984), conhecendo muito ampla divulgação os seus livros de histórias para crianças: $O$ rapaz de bronze (1956), A menina do mar (1958), A fada Oriana (1958), Noite de Natal (1960), O cavaleiro da Dinamarca (1964) e A floresta (1968).

Autora de peças de teatro, Sophia tem ainda uma vasta obra, aliás menos estudada, quer como ensaísta - veja-se o volume $O$ nu na Antiguidade Clássica (1975) -, quer como tradutora, por exemplo da

terra, pode de repente destruir a obra da geometria, da transparência, da... Vivemos à beira de um abismo que não é redutível... O caos de certa maneira revitaliza o cosmos, é uma fonte de energia e é isso o que o poeta sabe. Há uma dialéctica caos-cosmos em toda a obra de arte" (p. 4).

${ }^{3} \mathrm{Na}$ mesma entrevista a M. Armanda Passos (1982, p. 2), a poeta recordava também o primeiro contacto com a palavra poética: "O primeiro encontro com o poema foi quando me ensinaram a Nau Catrineta, o que já contei num texto chamado 'Como a poesia me criou'. Tinha três anos". 
Anunciação de Maria, de Paul Claudel (1960), de Purgatório, de Dante Alighieri (1961), de Hamlet, de Shakespeare, e de Medeia, de Eurípides, entre outras obras. ${ }^{4}$

\subsection{Sophia e a poesia do seu tempo}

Quando Sophia faz a sua entrada no mundo das letras, o campo literário era dominado pelos movimentos opostos de presencistas e neorrealistas. Novas gerações procuram então afirmar-se, nomeadamente o grupo dos Cadernos de Poesia, em que comparecem nomes como os de Jorge de Sena e de Ruy Cinatti, poetas com quem Sophia conviveu e alimentou estreito diálogo. Fértil para a literatura portuguesa, a década de 40 do século XX assinala, precisamente num mesmo ano, 1942, dois acontecimentos editoriais importantes: a inauguração, pela Ática, da famosa colecção com que deu a conhecer Fernando Pessoa (1888-1935), ele mesmo e os seus heterónimos, a um público alargado, e a publicação de Poemas, de Rainer Maria Rilke (1875-1926), em tradução de Paulo Quintela. Pessoa e Rilke serão dois faróis a iluminar a poesia portuguesa das duas décadas subsequentes.

Também Sophia não se eximiu ao diálogo com estes dois grandes vultos. Numa fase inicial, porém, é Rilke - que Sophia, segundo o seu próprio testemunho, conhecera logo em 1938 em tradução francesa de Maurice Betz $-^{5}$, quem detém uma presença mais nítida e mais forte na

\footnotetext{
${ }^{4}$ Destaque-se o prefácio que Sophia escreveu para a tradução de Hamlet, de Shakespeare (1987, Porto, Lello \& Irmão Editores), em que tece interessantes considerações sobre as dificuldades que se põem à tradução dos clássicos, como também - com particular a propósito para o filão da recepção de temas gregos em Sophia - a tradução, publicada postumamente, de Medeia, de Eurípides (2006, Lisboa, Caminho), levada à cena no mesmo ano, no Teatro Nacional D. Maria II, com dramaturgia e encenação de Fernanda Lapa.

${ }^{5}$ Sophia é porventura a poeta portuguesa cujo nome mais pronta e imediatamente se vincula ao de Rilke. Para além de afinidades intrínsecas, terá sido determinante o facto de ter travado contacto com Rilke, um contacto marcado pelo deslumbramento, em pleno período de aprendizagem poética. Quanto à data e ao veículo desse encontro, a própria poeta esclareceu, por ocasião das comemorações do centenário do nascimento de Rilke na Universidade de Coimbra, em 1976, que o conhecera através de Poésie,
} 
sua obra. ${ }^{6}$ Mais tarde a poeta confirma esta linhagem rilkiana. À pergunta directa: "Como escritora, sente-se influenciada por Rilke?", responde numa entrevista de 1987, publicada no Diário de Notícias (Tomé: VI), com estas significativas palavras:

Rilke, quando o li pela primeira vez, foi para mim uma revelação, porque nesse tempo da minha adolescência eu tinha lido muita poesia, desde Homero, até Verlaine, passando pela Bíblia, Camões, Antero, Baudelaire, António Nobre, Byron, Horácio, Ovídio. Mas quase não conhecia poesia do século XX. Nem Pascoais tinha lido. Por isso Rilke foi para mim uma linguagem nova. Mas é-me difícil saber em que medida me influenciou, porque nos poemas que eu tinha escrito antes de o ler, mesmo nos primeiros poemas balbuciantes, já havia algo de rilkiano. É evidente que muitos poemas me influenciaram, sobretudo na minha juventude. Penso, por exemplo, que fui influenciada nesse tempo pelas metáforas de Lorca, que são metáforas redondas, que dão a volta. São como aqueles quadros de Picasso em que uma cara se vê ao mesmo tempo de lado e de frente. E, na época em que escrevi o "Coral" fui influenciada por Ruy Cinatti. Fui, também, muitas vezes influenciada pela pintura moderna e antiga.

Mas em mim a influência mais real foi certamente Camões e também Antero.

Por outro lado, o fenómeno Pessoa vai-se-lhe impondo de forma talvez menos perceptível mas gradual, ${ }^{7}$ acabando por reclamar-lhe, já

a tradução francesa de Betz, volume de que adquirira um exemplar logo em 1938 (cf. Hörster 2001, p. 528).

${ }^{6}$ Muitos foram os críticos e os companheiros de letras que logo a partir da sua estreia poética a aproximam de Rilke (cf. Hörster 2001, p. 528 ss).

${ }^{7}$ Já numa entrevista de 1957 (cf. MOURA, p. 5), Sophia evidencia o seu reconhecimento do extraordinário valor de Fernando Pessoa. Tendo-lhe sido perguntado "e qual a produção artística [em Portugal] de nível mais alto?”, Sophia responde: "É a poesia, que não depende nem de público nem de encomendas nem de empresários. A nossa 
numa fase de maior maturidade, dois notáveis retratos-diálogo, ${ }^{8}$ que constituem o objecto principal deste nosso estudo. Registe-se que, no quadro de leituras traçado por Sophia, ${ }^{9}$ não comparece o nome do grande poeta modernista português, e a ausência da sua figura tutelar no horizonte dos primeiros livros da poeta é também registada por Eduardo Lourenço com as seguintes palavras: "E da avassaladora presença de Pessoa nos anos quarenta e cinquenta não se vislumbra na autora de Dia do mar e de Coral, aparentemente, um sinal de conivência" (1978, p. IV). E o crítico prossegue (1978: IV-V):

Na topologia da nossa aventura poética, Sophia e Pessoa ocupam os pólos opostos e nesse sentido a poesia de Sophia, de uma maneira bem diversa e muito mais radical que a de poetas que conscientemente se quiseram outros que Pessoa, inaugura ou põe termo à longa travessia da consciência poética como consciência infeliz que começa em Antero e tem em Álvaro de Campos a sua expressão "épica". (LOURENÇO, 1978, p. IV-V).

Esta posição de Eduardo Lourenço mereceu, no entanto, algumas reticências a Martinho, que, num texto em que se debruça sobre a leitura que Sophia faz de Pessoa, começa por chamar a atenção para afirmações de Jorge de Sena (1982, p. 26); assim, já em 1958, aquando da organização da terceira série das Líricas portuguesas, Sena afirmara que "a nobreza de dicção" - marcante em Sophia - era "irmã da majestade subtil de Pascoaes e das grandes odes de Álvaro de Campos, cuja linhagem continuava”.

poesia moderna é magnífica. Teixeira de Pascoais e Fernando Pessoa são dois dos maiores poetas que conheço, em qualquer país e em qualquer época".

${ }^{8}$ É esta a categoria que Eduardo Lourenço propõe para classificar estes dois poemas (cf. LOURENÇO, 1978, p. V).

${ }^{9} \mathrm{O}$ seu horizonte de leituras não se restringe ao atrás traçado. Veja-se, por exemplo, o testemunho constante de uma entrevista de 1957 (Moura). À pergunta "Além de Camões que já citou, quais são os autores que mais lê?", responde: "Homero, a Bíblia, Dante, Hölderlin, Rimbaud, Rilke, Lorca, Pierre Emmanuel, Eluard, etc.". "E portugueses?", pergunta-se de novo. Resposta: "Teixeira de Pascoais, Fernando Pessoa, Torga, Régio, Ruy Cinatti, Jorge de Sena...”. 
Daí Martinho retira a conclusão de que, ainda que de forma difusa, "e mais ao nível da 'dicção' e do tom, era já visível em Sophia, antes de Livro sexto, a leitura 'por dentro' de Pessoa".

Mais visível se torna o diálogo de Sophia com o grande poeta modernista nos poemas que the veio a dedicar: "Fernando Pessoa", de Livro sexto (1962; cf. Obra poética, p. 466); o conjunto "Homenagem a Ricardo Reis”, de Dual (1972; cf. Obra poética, p. 597-605); “"Fernando Pessoa' ou 'Poeta em Lisboa'”, de O nome das coisas (1972; cf. Obra poética, p. 661); "Fernando Pessoa", de Musa (1994; cf. Obra poética, p. 856). ${ }^{10}$

\subsection{Sophia e Pessoa}

Se nas primeiras colectâneas de Sophia ainda podemos detectar alguns traços nórdicos e neorromânticos, a dupla descoberta do Sul (do Algarve ${ }^{11} \mathrm{e}$ da Grécia) contribui para firmar o filão de luminosidade, clareza e precisão que toda a crítica andreseniana tem realçado. A viagem à Grécia (em setembro de 1963, na companhia de Agustina Bessa Luís e seu marido Alberto Luís) veio permitir um diálogo entre uma imagem virtual, montada a partir das leituras de Homero, ${ }^{12}$ com o impacto violento do confronto com o real grego em toda a sua plenitude.

Quem faça uma leitura sequencial dos volumes líricos de Sophia de Mello Breyner Andresen notará, não sem alguma surpresa, que uma série de poemas em que a poeta se confronta com a vida e a obra de Fernando Pessoa (1888-1935) nasce de vivências gregas - circunstância que por

\footnotetext{
${ }^{10}$ Em entrevista concedida ao Jornal das Letras (2011, p. 7), aquando da doação do espólio de Sophia à Biblioteca Nacional, a sua filha Maria Andresen deu notícia da existência de um texto em prosa poética dedicado a Pessoa: "Há um conto inédito incompleto e vários esboços. E uma série de tentativas autobiográficas. [...] e há, por exemplo, o princípio de um conto sobre Fernando Pessoa, que é muito interessante". ${ }^{11} \mathrm{O}$ seu filho Miguel Sousa Tavares recorda a Granja como uma praia de "água gelada e nevoeiro", "uma praia tão má que se tomava banho na piscina"; tinha ele 10 ou 11 anos. "Mas depois, em 1961, fomos para o Algarve. Na praia D. Ana havia uma pensão e três casas. [...] Fomos uns 10 anos para essa casa. Depois para Vale de Lobos e Vilamoura, mas deu-nos nostalgia de Lagos" (COELHO, 2009, p. 6-7).

12 "Homero" é título dado por Sophia a um conto, em que trata da sua primeira experiência da poesia.
} 
vezes aparece expressamente assinalada logo no título ou na epígrafe de algumas composições. A impressão que se colhe é a de que o enigma Fernando Pessoa se lhe impôs de forma premente quando Sophia, nas suas viagens, se acerca do mar e da terra grega. Que razão ou razões poderão estar por detrás de tão inesperada associação? Esta foi a interrogação que de imediato se nos colocou e nos obrigou a tentar encontrar respostas.

\section{Os poemas "Em Hydra, evocando Fernando Pessoa" e "Cíclades": uma leitura}

Centramos agora a nossa atenção em dois poemas, o primeiro, de junho de 1970, inserido no ciclo “Arquipélago”, do livro Dual (1972), e o segundo, de 1972, constante de O nome das coisas (1977). Como os próprios títulos indicam, um e outro poemas partem de uma vivência da Grécia insular, sugestiva de uma evocação de Fernando Pessoa.

\section{1 "Imagino que viajasses neste barco"}

\section{Em Hydra, evocando Fernando Pessoa}

Quando na manhã de Junho o navio ancorou em Hydra (E foi pelo som do cabo a descer que eu soube que ancorava) Saí da cabine e debrucei-me ávida Sobre o rosto do real - mais preciso e mais novo do que o imaginado

Ante a meticulosa limpidez dessa manhã num porto Ante a meticulosa limpidez dessa manhã num porto de uma

Murmurei teu nome [ilha grega

O teu ambíguo nome

Invoquei a tua sombra transparente e solene

Como esguia mastreação de veleiro

E acreditei firmemente que tu vias a manhã

Porque a tua alma foi visual até aos ossos

Impessoal até aos ossos

Segundo a lei de máscara do teu nome

Odysseus - persona 
Pois de ilha em ilha todo te percorreste

Desde a praia onde se erguia uma palmeira chamada Nausikaa Até às rochas negras onde reina o cantar estridente das sereias

O casario de Hydra vê-se nas águas

A tua ausência emerge de repente a meu lado no deck deste barco E vem comigo pelas ruas onde procuro alguém

Imagino que viajasses neste barco Alheio ao rumor secundário dos turistas

Atento à rápida alegria dos golfinhos

Por entre o desdobrado azul dos arquipélagos

Estendido à popa sob o voo incrível

Das gaivotas de que o sol espalha impetuosas pétalas

Nas ruínas de Epheso na avenida que desce até onde esteve o mar Ele estava à esquerda entre colunas imperiais quebradas

Disse-me que tinha conhecido todos os deuses

E que tinha corrido as sete partidas

O seu rosto era belo e gasto como o rosto de uma estátua roída [pelo mar

Odysseus

Mesmo que me prometas a imortalidade voltarei para casa Onde estão as coisas que plantei e fiz crescer

Onde estão as paredes que pintei de branco

Há na manhã de Hydra uma claridade que é tua

Há nas coisas de Hydra uma concisão visual que é tua

Há nas coisas de Hydra a nitidez que penetra aquilo que é [olhado por um deus

Aquilo que o olhar de um deus tornou impetuosamente presenteNa manhã de Hydra

No café da praça em frente ao cais vi sobre as mesas

Uma disponibilidade transparente e nua

Que te pertence

O teu destino deveria ter passado neste porto

Onde tudo se torna impessoal e livre

Onde tudo é divino como convém ao real

(Obra poética, p. 626-627) 
Numa afirmação poética de raiz biográfica, não muito frequente em Sophia, ${ }^{13}$ é-nos apresentada, como uma vivência do sujeito poético, a chegada à ilha grega de Hidra. Um eu lírico de sentidos despertos abre-se a estímulos de ordem auditiva e visual, ${ }_{14}^{14}$ indagando ávido um real que, na sua nitidez e primordialidade, supera a projecção antes intimamente elaborada.

As duas estrofes seguintes de alguma forma funcionam como proémio do poema. Por um lado, a limpidez é de tal forma excessiva que obriga o sujeito poético a registar em duplicado essa impressão primeira. "A meticulosa limpidez" de uma "manhã num porto" é sempre uma imagem de luminosidade e abertura, mas, se acrescida por "de uma ilha grega", ganha ainda a força de uma superlativação. Suporte desta impressão geral é a série de substantivos concretos, ${ }^{15}$ precisados por um único adjectivo - "meticulosa" -, que nada tem de ornamental. ${ }^{16}$ Ao mesmo tempo, a anáfora reforça a veracidade da informação, dando peso à componente biográfica.

${ }^{13}$ Numa recensão a No tempo dividido, Mourão-Ferreira (1980, p. 174), sublinhava a ausência de biografismo na poesia da escritora: "A voz de Sophia de Mello Breyner Andresen ergue-se com uma pureza inusitada completamente isenta de biografismo, de expressão retórica, de teatralidade, de pitoresco - e de toda aquela imediatez interjectiva, tão frequente na poesia feminina". Despida da sua radicalidade, esta afirmação de Mourão-Ferreira aplica-se a muito da poesia de Sophia. A própria Sophia, numa entrevista dada a Maria Maia (Jornal de Poesia, Lisboa, 10 de maio de 2000, p. 49; cf. CECCUCCI, 2011, p. 25), afirmava: "Eu não sei a diferença entre interior e exterior. Eu vejo com os olhos, ouço com os ouvidos [...]. Quanto à minha poesia [...] tem uma parte de cultura, tem uma parte intelectual. Mas tem uma parte vivida". Logo, após a captura da sensação, Sophia reconhece a elaboração interior em que memória e cultura intervêm.

${ }^{14}$ Martinho (1982, p. 27) interpreta a insistência no "olhar" que percorre todo o poema como uma homenagem a Alberto Caeiro. Sem pôr em causa esta dimensão, diríamos, no entanto, que "ver" é uma lição que Sophia colheu em Rilke. Ela própria, em entrevista a A. Moura (1957, p. 5), à pergunta sobre qual a missão do poeta, responde: "Olhar, ver e dizer o que viu".

${ }^{15}$ Segundo o testemunho de Maria Andresen Sousa Tavares, no prefácio de Obra poética (p. 31), o poeta brasileiro João Cabral de Melo Neto, na primeira conversa que teve com Sophia, terá dito: "Gosto muito da sua poesia, tem muito substantivo concreto". ${ }^{16}$ Sobre a propriedade rigorosa da adjectivação em Sophia, Prado Coelho (1980, p. 21) sintetizou: "Estes adjectivos (azul, verde, escura) não adornam, informam; são verificações de uma experiência visual, o dizer exacto do que é". 
O eu poético, como que obedecendo a uma força mágica, é levado a murmurar o nome de um "tu", que por enquanto, no corpo do poema, permanece anónimo. A estratégia de repetição que já encontrámos atrás encontra-se também nos dois versos seguintes desta estrofe proémica, incidindo agora em "nome". Mas o nome, que é, em princípio, factor de identificação e individualização, por um processo de paraprosdokían, causado pelo adjectivo "ambíguo", conduz antes a uma aporia.

O sujeito poético vai então construindo um perfil desse interlocutor invocado, em torno de semas que sublinham a imaterialidade ("a tua sombra transparente"), mas também a solenidade e a justeza ("e solene/ como esguia mastreação de veleiro"). ${ }^{17}$ Esboça-se um momento de afinidade entre ambos: numa afirmação de fé, a voz poética acredita que esse "tu" é capaz de partilhar a experiência visual daquela manhã - e no entanto, esse "tu" continua imaterial, na medida em que vê, não com os olhos, mas com a alma. O perfil vai-se enriquecendo ainda com o sema da impessoalidade; mais do que inexistente, esse "tu" é impessoal porque em constante jogo com a máscara. Chega-se finalmente à enunciação do nome, ele mesmo duplo e ambíguo, "Odysseus - Persona". Por um lado, Sophia explora a conhecida aproximação entre o nome do poeta português Fernando Pessoa e o substantivo latino para "máscara", persona. Menos comum é a associação com a figura mítica de Ulisses, "o dos mil artifícios" (polyméchanos), que, como Pessoa, em busca da sua verdadeira identidade, se desdobrou em múltiplas personae.

A menção deste duplo nome por um lado fecha o proémio, ao mesmo tempo que abre o desenvolvimento dos temas enunciados. Central é a identificação de Ulisses e Pessoa como protagonistas de uma errância, que tem por fim último a busca da identidade: tal como Ulisses é agente de um percurso fracturado "de ilha em ilha", Pessoa concretiza a sua viagem em termos literários, repartindo-se pelos diversos heterónimos. O uso reflexo do verbo "percorrer", numa expressão incomum, dá bem a dimensão interior e de autoindagação da viagem pessoana, que é metaforizada através do itinerário de Ulisses. Esse trajecto íntimo pelas várias ilhas de si mesmo é assinalado por duas referências homéricas, que

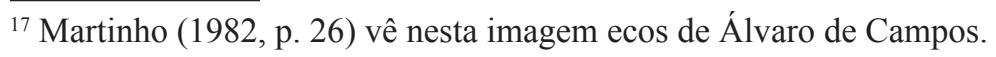


simbolizam os dois grandes polos da salvação e da perdição: Nausícaa e as sereias. ${ }^{18}$ Com esta equiparação, é como se Sophia acrescentasse a Fernando Pessoa um novo heterónimo.

Depois desta breve incursão pela personalidade de Pessoa, retorna-se ao cenário inicial do poema: "O casario de Hydra vê-se nas águas". De novo se instaura a oposição entre a visibilidade luminosa de uma ilha mediterrânica e, com ela, a evocação de Pessoa. Sem nomear o seu interlocutor, Sophia sente-o presente sob o signo da ausência, prolongando-lhe a imaterialidade. São agora companheiros de viagem, partilhando Sophia com o poeta da Mensagem a experiência de quem navega pelo Mediterrâneo. Imagina-o concentrado no que é essencial, desatento ao "rumor secundário dos turistas". Em íntima cumplicidade com as reacções do eu poético, este Pessoa imaginário estaria receptivo à face solar da natureza: "a alegria dos golfinhos" motivo recorrente em Sophia, ${ }^{19}$ o "desdobrado azul dos arquipélagos", numa hipálage em que a impressão da cor do mar se projecta sobre as ilhas, e "o voo incrível das gaivotas”, num efeito potenciado pelo próprio sol.

${ }^{18} \mathrm{O}$ encontro de Ulisses com Nausícaa e as sereias, como exemplo das múltiplas entidades femininas com que o herói de Ítaca se depara no seu trajecto de regresso, implica dois tipos de aventura contrapostos. Nausícaa, a princesa dos Feaces, que acolhe o náufrago Ulisses e lhe facilita o acesso à autoridade do lugar, funciona como uma das suas aliadas (Odisseia, VI, 255-315). Em contrapartida, as sereias, caracterizadas no mito pelo canto persuasivo mas destruidor, constituem para o navegante uma tremenda ameaça (Odisseia, XII, 39-54, 165-198). De cada uma destas entidades, Sophia preserva os que são os símbolos convencionais: a praia e a palmeira, no caso de Nausícaa (Odisseia, VI, 85-100, 161-168), e as rochas negras como cenário em que se movem as sereias. $\mathrm{O}$ ambiente luminoso e aberto da praia, promissor de verdade e segurança, contrasta, portanto, com o negrume dos rochedos, onde se oculta o fascínio perigoso da mentira.

19 Menções semelhantes à alegria dos golfinhos, vinculada à paisagem grega, comparecem igualmente nos poemas "Cíclades" - "Estes são os rápidos golfinhos da tua alegria" (Obra poética, p. 652) - e "Crepúsculo dos deuses" - "Como golfinhos a alegria rápida/ Rodeava os navios" (Obra poética, p. 556). Não é esta a única vez em que Sophia recorre à autocitação. De acordo com Martinho, o verso "Que te quiseste distante como quem ante o quadro pra melhor ver recua" retoma três versos do sexto poema do conjunto "Homenagem a Ricardo Reis", de Dual (Obra poética, p. 604): "Distante me desejo/ Como quem ante o quadro/ Pra melhor ver recua". 
O seu trajecto leva-os a Éfeso, a contrapartida cultural do que Hidra é do ponto de vista da physis. Símbolo de um clímax artístico, com o seu templo de Ártemis, uma das sete maravilhas do mundo antigo, ${ }^{20} \mathrm{e}$ intelectual, com a biblioteca de Celso, Éfeso representa a fusão do espírito grego e do romano, fundamento da cultura ocidental. É nesse cenário que visionam um "ele", certamente Ulisses, o paradigma do viajante, com quem travam um diálogo imaginário. ${ }^{21}$

Esta figura anónima, curtida pelo desgaste do mar, adquire uma dimensão estatuária, como que retirada ao fluxo do tempo. Por ter atravessado as eras, as palavras que saem da sua boca revestem-se de uma autoridade oracular. Ainda que tendo conhecido todos os deuses e percorrido os sete cantos do mundo, o seu objectivo supremo é, porém, o do regresso a casa. ${ }^{22}$ As suas palavras repercutem as que o Ulisses homérico pronunciou diante de Calipso, quando esta lhe oferecia a imortalidade se permanecesse na sua ilha (Odisseia, V, 203-220). Como homem, Ulisses vê a sua realização não no estatuto de imortal, mas no cumprimento das tarefas simples de uma vida humana, na sua ligação ao lugar que o viu nascer. A menção das "paredes brancas" da casa, o papel em que o homem deixa inscrita a sua passagem pela terra, contrasta, pela simplicidade, com a magnitude e imponência artística de uma das sete maravilhas do mundo, o templo de Éfeso, onde Ártemis tem o seu culto.

${ }^{20}$ Sobre o templo de Ártemis em Éfeso, cf. FERREIRA, J. R., FERREIRA, L. N. (2009), As sete maravilhas do mundo antigo, p. 57-64.

${ }^{21}$ Esta figura ambígua, em que nos inclinamos a ver uma referência a Ulisses, é por Martinho (1982, p. 27) identificada com o próprio Fernando Pessoa.

${ }^{22}$ Neste desejo de retorno a casa por parte de Ulisses, Sophia projecta a sua própria experiência pessoal. Aquando da sua primeira viagem à Grécia, em setembro de 1963, aponta num caderno: "Ao fim da tarde fomos à Acrópole. Beleza inigualável, leve brisa, mar brilhando ao longe. Maravilhoso o enquadramento na paisagem. Mar de pedras à roda do Parténon. Tirei muitas fotografias. Mas tal como o Ulisses estou sempre a pensar na minha casa" (cf. COELHO, 2009, p. 5-6). O sentido de pertença a uma casa e a ideia do caminho para ela ressalta também de uma frase que integrava o património imaginário da família Andresen. O bisavô dinamarquês de Sophia, que, atravessando o mar, se fixaria na cidade do Porto, disse uma vez a uma neta: "O mar é o caminho para a minha casa" (PEREIRA, 1985, p. 3). 
Depois desta incursão por territórios de cultura grega, a resposta de Ulisses a Calipso cria a ideia do retorno, que no poema se concretiza por um regresso à imagem inicial de uma esplendorosa Hidra. Contrastando com o desgaste da paisagem construída por acção do tempo - em Éfeso as colunas imperiais encontram-se quebradas e os rostos das estátuas, roídos pelo mar -, Hidra é evocada de novo numa plenitude intocada que mantém a sua eterna nitidez. À semelhança do que acontecera no início do poema, também aqui o impacto visual do cenário é sublinhado pelo emprego de figuras de repetição, como sejam a anáfora e a epífora. Insistente é também uma outra imagem, a de que a paisagem é como é porque olhada por um deus.

Mas logo, numa espécie de anáfora imperfeita - "Na manhã de Hydra" -, acompanhamos o olhar do eu poético fixando-nos numa paisagem social - "no café da praça em frente ao cais". No poema, a paisagem natural é pontuada por algumas, poucas, referências a artefactos ou construções humanas, simbólicos: o navio, marca de viagem exterior ou interior; o casario, símbolo da fixação humana a um lugar; o porto, símbolo de chegada e de partida; o templo com as suas colunas quebradas, símbolo da presença divina e da acção desgastante do tempo. E, aparentemente destoando desta série, a mesa do café. A uma segunda leitura, porém, também esta adquire uma dimensão simbólica. Uma mesa de café em Lisboa, em recanto fechado e sombrio, é o contexto em que Pessoa, no nosso imaginário, viveu e criou. ${ }^{23}$ Em contrapartida, o café da praça de Hidra, em frente ao cais, num espaço aberto, de amplitude marítima, oferece um real que, por direito, estaria à altura de Pessoa. $\mathrm{O}$

\footnotetext{
${ }^{23}$ Incontornável é aqui a remissão para o célebre quadro de Almada Negreiros (1964), que estiliza o poeta como criador solitário à mesa do café. Este mesmo imaginário concretizou-se na estátua que hoje se encontra diante do café da Brasileira do Chiado, um dos pontos do percurso lisboeta do poeta. A própria Sophia dedicou à mesma imagem de Pessoa à mesa do café o poema "Fernando Pessoa", de julho de 1994, inserido em Musa (cf. Obra poética, p. 856): Com o sobretudo abotoado até ao queixo/ Embiocado afastado/ No lugar mais escuro do café escrevia/ O múltiplo poema o canto inumerável/ Arrancado ao desejo à paixão à memória/ Às lucidíssimas fúrias da renúncia.
} 
poema envereda então por considerações judiciosas: na avaliação do eu poético, foi uma perda Pessoa não ter experienciado a dimensão plena e divina que o real pode ter na Grécia. A mesa do café atinge neste contexto uma dimensão mítica, como cenário da criação poética pessoana.

\section{2 "Esquartejado pelas fúrias do não-vivido"}

\section{Cíclades}

(evocando Fernando Pessoa)

A claridade frontal do lugar impõe-me a tua presença

O teu nome emerge como se aqui

O negativo que foste de ti se revelasse

Viveste no avesso

Viajante incessante do inverso

Isento de ti próprio

Viúvo de ti próprio

Em Lisboa cenário da vida

E eras o inquilino de um quarto alugado por cima de uma leitaria

O empregado competente de uma casa comercial

$\mathrm{O}$ frequentador irónico delicado e cortês dos cafés da Baixa

$\mathrm{O}$ visionário discreto dos cafés virados para o Tejo

(Onde ainda no mármore das mesas

Buscamos o rastro frio das tuas mãos

- O imperceptível dedilhar das tuas mãos)

Esquartejado pelas fúrias do não-vivido

À margem de ti dos outros e da vida

Mantiveste em dia os teus cadernos todos

Com meticulosa exactidão desenhaste os mapas

Das múltiplas navegações da tua ausência-

Aquilo que não foi nem foste ficou dito

Como ilha surgida a barlavento

Com prumos sondas astrolábios bússolas

Procedeste ao levantamento do desterro

Nasceste depois

E alguém gastara em si toda a verdade

O caminho da Índia já fora descoberto 
Dos deuses só restava

$\mathrm{O}$ incerto perpassar

No murmúrio e no cheiro das paisagens

E tinhas muitos rostos

Para que não sendo ninguém dissesses tudo

Viajavas no avesso no inverso no adverso

Porém obstinada eu invoco - ó dividido -

$\mathrm{O}$ instante que te unisse

E celebro a tua chegada às ilhas onde jamais estiveste

Estes são os arquipélagos que derivam ao longo do teu rosto

Estes são os rápidos golfinhos da tua alegria

Que os deuses não te deram nem quiseste

Este é o país onde a carne das estátuas como choupos estremece Atravessa pelo atravessar leve da luz

Aqui brilha o azul-respiração das coisas

Nas praias onde há um espelho voltado para o mar

Aqui o enigma que me interroga desde sempre

É mais nu e veemente e por isso te invoco:

"Porque foram quebrados os teus gestos?

Quem te cercou de muros e de abismos?

Quem derramou no chão os teus segredos?"

Invoco-te como se chegasses neste barco

E poisasses os teus pés nas ilhas

E a sua excessiva proximidade te invadisse

Como um rosto amado debruçado sobre ti

No estio deste lugar chamo por ti

Que hibernaste a própria vida como o animal na estação adversa Que te quiseste distante como quem ante o quadro pra melhor

[ver recua

E quiseste a distância que sofreste

Chamo por ti - reúno os destroços as ruínas os pedaços -

Porque o mundo estalou como pedreira

E no chão rolam capitéis e braços

Colunas divididas estilhaços

E da ânfora resta o espalhamento de cacos

Perante os quais os deuses se tornam estrangeiros 
Porém aqui as deusas cor de trigo

Erguem a longa harpa dos seus dedos

E encantam o sol azul onde te invoco

Onde invoco a palavra impessoal da tua ausência

Pudesse o instante da festa romper o teu luto

$\mathrm{O}$ viúvo de ti mesmo

E que ser e estar coincidissem

No um da boda

Como se o teu navio te esperasse em Thasos

Como se Penélope

Nos seus quartos altos

Entre seus cabelos te fiasse

(Obra poética, p. 651-653)

Se, neste caso, o nome de Fernando Pessoa não integra o título, a epígrafe não deixa dúvidas sobre a intenção de Sophia. É flagrante a semelhança com "Em Hydra, evocando Fernando Pessoa" no que respeita ao seu incipit: o poema abre com a imagem de um lugar caracterizado por uma "claridade frontal", do qual "emerge" - e o verbo já comparecia no poema anterior (v. 20) - o nome e, com ele, a presença de Pessoa. Confirmando a proverbial abertura de Sophia à dimensão do olhar, a personalidade pessoana é erguida através de uma imagética fotográfica, identificando-se Pessoa como um negativo, que sairia da sua sombra e se revelaria na plena luminosidade daquele espaço.

A estrofe seguinte passa a esboçar o retrato convencional do quotidiano lisboeta de Pessoa, sublinhando Sophia a relação antinómica entre o ser e o parecer, a presença e a ausência: "viveste no avesso/ Viajante incessante do inverso/ Isento de ti próprio/ Viúvo de ti próprio". A estrofe ela mesma desenvolve-se numa lógica de verso e anverso: à avaliação conceptual e metafórica do que foi a relação vida e obra de Pessoa, seguem-se tópicos biográficos de grande concretismo. Um exterior marcado pela rotina, pelo apagamento e pela modéstia é a face visível sob a qual se oculta um turbilhão intelectual de alcance insuspeitado. Este é o Pessoa que, evitando a criação de vínculos de toda a ordem, habitou em quartos alugados, esteve ao serviço de diferentes casas comerciais desempenhando funções subalternas de escriturário e 
tradutor, ${ }^{24}$ e assumiu o papel convencional de frequentador "delicado e cortês dos cafés da Baixa". ${ }^{25}$ A menção dos cafés voltados para o Tejo ${ }^{26}$ abre porém, na rotina de Pessoa, a dimensão visionária que corresponde à sua verdadeira natureza. $\mathrm{O}$ Tejo funciona como uma porta de saída para o sonho, a especulação, a liberdade de pensamento.

As fúrias, ${ }^{27}$ entidades vingativas aqui com um campo de intervenção específico - "fúrias do não-vivido" ${ }^{28}$, intervêm, esquartejando o prevaricador, imagem sob a qual se desenha o fenómeno da heteronímia. Assim, ao mesmo tempo que punem, as fúrias abrem espaço para a criação especificamente pessoana. No poema, este verso funciona, portanto, como charneira entre a banalidade do quotidiano exterior e a total liberdade interior que identificou Pessoa.

No espaço de ausência que se garantiu ("à margem de ti dos outros e da vida"), este novo Ulisses encontrou a liberdade para se entregar a arrojadas navegações interiores, sob o signo, não da deriva, mas da ponderação, da exactidão e do rigor, como sugere a metafórica náutica que informa a segunda metade da estrofe. Repercutindo a epopeia dos Descobrimentos, a escrita é aqui a ilha do achamento, criadora de uma outra realidade, que se substitui ao real e o supera: "Aquilo que não foi nem foste ficou dito". Exacto cartógrafo da alma, Pessoa procedeu ao minucioso "levantamento do desterro", imagem dúplice com que, por um lado, mais uma vez se evoca o tema do exílio, mas também o levantar da âncora para amplas e livres navegações.

\footnotetext{
${ }^{24}$ Esta condição de vida de uma grandeza insuspeitada no meio de um quotidiano corriqueiro e apagado é o tema da novela de Mário Cláudio Boa noite, Senhor Soares (2008). Aqui, a personagem de grandeza mítica contra a qual há-de ler-se a mediania da sociedade portuguesa é o anónimo Senhor Soares, afinal Bernardo Soares, o autor do Livro do desassossego, em representação metonímica da constelação pessoana.

${ }^{25}$ De acordo com Martinho (1982, p. 27), estes apontamentos denotam o conhecimento que Sophia teve da biografia de Pessoa escrita por João Gaspar Simões.

${ }^{26}$ Martinho (1982, p. 27) vê neste verso "uma reminiscência da 'Ode ao Tejo e à Memória de Álvaro de Campos', de Adolfo Casais Monteiro".

${ }^{27}$ As fúrias são deusas que não tomam iniciativas de perseguição; a sua actuação é automática sobre o crime cometido e a dimensão da vingança, simétrica com a própria gravidade do acto criminoso a punir.

${ }^{28}$ Imagem semelhante comparece no poema "Fernando Pessoa", de Musa. Cf. a nota 17 deste artigo.
} 
Sophia concede seguidamente algum espaço à ideia de que o poeta de Orpheu é um vindouro tardio, terminada que fora a grande epopeia dos portugueses, por um lado, e, por outro, reduzida a presença viva dos deuses na natureza à experiência de frágeis e efémeras impressões - "um murmúrio", um "cheiro das paisagens". Concluídas as grandes tarefas e esbatidas as grandes etapas culturais do Ocidente, Pessoa afunda-se no seu íntimo e desdobra-se: "E tinhas muitos rostos/ Para que não sendo ninguém dissesses tudo". Nestes dois versos, pode ler-se mais uma vez a sobreposição de Pessoa e Ulisses (cf. poema "Em Hydra, evocando Fernando Pessoa"): tal como o Ulisses homérico, na sua itinerância, reveste personalidades e atitudes diversas em função dos seus diferentes interlocutores, mas quando questionado sobre a sua identidade responde com "Ninguém" (Odisseia, IX, 366), também Pessoa, com o jogo heteronímico, abdicou de uma identidade única para potenciar a sua criação.

Depois destas imagens de vazio, abre-se um novo arco poético, que se ergue triunfante até ao clímax final. É como se o eu lírico não se conformasse e visionariamente ideasse para o "dividido" um outro projecto de vida, em que como grande aliada the surge esta paisagem grega - com as suas ilhas, a sua alegria, a sua luz, graça e plenitude..$^{29} \mathrm{E}$ como se Sophia conscientemente retomasse o gesto utópico e "maternal" do poema anterior, imaginando que uma vinda nunca concretizada de Pessoa às ilhas gregas pudesse realizar o milagre da união.

Recupera-se agora, do poema anterior, a antinomia Grécia/ Fernando Pessoa, sustentada em imagens e cadeias metafóricas semelhantes: a Grécia, caracterizada pelos logótipos "arquipélagos" e

\footnotetext{
${ }^{29}$ Referindo-se ao poeta em geral e ao seu papel, afirma Clara Rocha, em Biblos, s. v. "Andresen": "Exilado num 'tempo dividido', o poeta demanda a unidade de um tempo arquetípico, povoado de deuses. O tempo presente é um tempo estilhaçado, destroçado, habitado pelas Fúrias que desceram do Olimpo para reinar sobre a trivialidade do quotidiano [...]. Contra ele, a poesia obstina-se na procura de um tempo uno, perfeito e inteiro. Encontra-o no paradigma natural ('a verdade antiga da natureza', que inspira alguns dos mais belos momentos de Sophia) e também no paradigma civilizacional grego, profundamente admirado [...] e identificado com valores de justiça, harmonia e beleza". ${ }^{30}$ Esta caracterização da atitude de Sophia como "maternal" encontra-se presente no Prefácio que Eduardo Lourenço escreveu para a já referida quarta edição de Antologia.
} 
“golfinhos", representa, na projecção eutópica de Sophia, um Pessoa ideal, uno e alegre, que ela lamenta não ter existido. A imagem da Grécia (tanto no poema anterior como neste) expressa uma unidade harmónica em que colaboraram deuses e homens: a physis (arquipélagos, mar, golfinhos, luz, céu, praias, choupos) e a construção artística (templos e estátuas). Por obra mágica da luz, estabelece-se uma intercomunicação de todos estes mundos - pedra, carne e flora -, que sofrem uma metamorfose. Esta vibração uníssona do mundo manifesta-se, ao próprio nível estilístico, através de personificações, sinestesias e comparações ("respirar leve da luz", "azul-respiração", "a carne das estátuas como choupos"). A remissão mútua entre os elementos convocados exprime-se ainda pela imagem surrealista de sabor magrittiano ${ }^{31}$ de um espelho nas praias, no qual confluem mar, terra e céu.

Num processo de autocitação, Sophia retoma três versos de um poema seu de autoquestionamento (Dia do mar, 1942; cf. Obra poética, p. 177), que agora adapta à evocação de Pessoa. A experiência de enigma, que numa primeira fase da sua criação sentira em relação a si mesma, é agora transferida para o seu interlocutor, o que significa que Sophia não vinca apenas as diferenças que a separam do poeta invocado, mas também traços de afinidade entre ambos. Nas sucessivas interrogações, unem-se os semas da divisão ("quebrados"), do isolamento ("muros"), da profundidade e do mistério ("abismos" e "segredos"). Este poema, em Dia do mar composto por quatro interrogações, surge aqui amputado do terceiro verso - "Quem desviou na noite os teus caminhos?"; assim se elimina a ideia negativa de "desvio", que Sophia certamente não quer assacar a Pessoa.

Sophia prossegue na imaginação de uma hipotética chegada de Pessoa às Cíclades. Com este motivo da chegada, consolida-se mais um factor de aproximação entre os dois poemas. Porém, enquanto o eu lírico do primeiro se lançava "ávido" sobre um real ansiado, desta vez, em relação quiástica, é o real que amorosamente se debruça sobre o recém-vindo, como que procurando seduzi-lo. Nesta dupla forma de conceber a chegada às ilhas gregas, Sophia vinca a distância que a separa do poeta invocado.

\footnotetext{
${ }^{31}$ A "misteriosa evidência" que Eduardo Prado Coelho destaca no famoso passo da Arte poética III, em que Sophia evoca a lembrança "dum quarto em frente do mar dentro do qual estava, poisada em cima duma mesa, uma maçã enorme e vermelha", leva-o a associar esta imagem à pintura de Magritte (COELHO, 1980, p. 22).
} 
O esforço necessário para trazer aquele que viveu do avesso à plena fruição da Grécia fica patente no apelo repetido que lhe é dirigido ("Chamo por ti"). A resistência pessoana ao fascínio daquele mundo é tanto maior quanto resulta de um acto de vontade. Foi por opção, vincada pelo duplo emprego de "quiseste", que Pessoa escolheu a distância.

Na ânsia de proporcionar ao "dividido" uma Grécia em toda a sua plenitude, Sophia propõe-se lutar contra o desgaste do tempo e reconstruir, a partir das ruínas, dos fragmentos e dos $\operatorname{cacos}^{32}$ que a povoam, o mundo antigo em toda a sua coesão. Quebraram-se os símbolos da aliança dos deuses com os homens, na degradação de templos e da ânfora. ${ }^{33} \mathrm{~A}$ ideia de que o passado pujante da Grécia se desmoronou, e de que os deuses, desfalcados do seu mundo, se retiraram, não é estranha ao pensamento

\footnotetext{
${ }^{32}$ Nestes versos, Martinho (1982, p. 28) identifica ecos do poema "Apontamento" de Álvaro Campos (1969, p. 378): "A minha alma partiu-se como um vaso vazio/ [...]/ Sou um espalhamento de cacos sobre um capacho por sacudir".

${ }^{33}$ Esta imagem da ânfora quebrada remete, de imediato, para aquela outra ânfora, que uma vez Sophia viu numa loja de barros em Lagos, e funcionou para ela como uma aliança com o sol (cf. Obra poética, p. 889): "Olho para a ânfora: quando a encher de água ela me dará de beber. Mas já agora ela me dá de beber. Paz e alegria, deslumbramento de estar no mundo, religação.
}

Olho para a ânfora na pequena loja dos barros. Aqui paira uma doce penumbra. Lá fora está o sol. A ânfora estabelece uma aliança entre mim e o sol."

Do significado que a ânfora para ela revestia, dá testemunho a cineasta Margarida Gil, que recorda um episódio na praia. Uma vez, em companhia de João César Monteiro, avistou "ao longe uma figura alada com uma túnica ocre e uma ânfora na mão, a passear, à beira-mar. Parecia uma aparição de uma deusa grega". Era Sophia (NUNES, 2011, p. 6). Num comentário ao que designa por "a famosa metáfora da ânfora", Ceccucci (2011, p. 19) sublinha a sua capacidade para mediar a ligação entre o sujeito poético e o belo das coisas reais: "a perfeição artística da ânfora, cuja própria realização harmoniosa, transmitida de geração em geração, provém da noite dos tempos, da civilização grega que, durante séculos, irradiou entre as gentes do Mediterrâneo, conformando-as e unificando-as no gosto e na procura do belo como modelo de vida e modalidade de comportamentos éticos, consequentemente e necessariamente submetidos à norma sob o signo da verdade e da justiça". E mais adiante continua: "na sua perfeição e plasticidade, que desenha e evoca nostalgicamente um mundo e uma época em que a aliança dos seres e das coisas 'reinava' no equilíbrio espiritual de cada pessoa". 
grego (veja-se, por exemplo, o mito de Tróia na versão das Troianas de Eurípides, onde dois deuses, Poseidon e Atena, se retiram daquela que, de cidade próspera e devota ao culto, se tornou numa mancha de cinzas).

As imagens de ruptura impostas pela evocação do poeta português não logram, porém, vencer a plenitude que a envolvência grega transmite. De facto, a grandeza da Grécia mantém-se viva na imaterialidade do seu pensamento, palavras e melodias, de que as Musas detêm a competência. Vivas permanecem e prevalecem "as deusas cor de trigo". Os efeitos mágicos deste mundo cultural, da música e do pensamento, repercutem na própria natureza. Natureza, património construído e pensamento abstracto formam, na Grécia, um todo harmónico e entre si cúmplice. ${ }^{34}$

O final do poema exprime a aspiração de Sophia de que a festa prevalecesse sobre o luto: de que Pessoa pudesse, enfim, abandonar o seu estatuto de viúvo e participar em pleno da "boda" que a Grécia oferece; de que "ser e estar coincidissem", ou seja, que a transitoriedade fosse integrada e assimilada à essencialidade, de que a ausência fosse transformada em existência plena. A culminar, apresenta-se uma imagem de Pessoa que, qual Ulisses, tivesse em Thasos ${ }^{35}$ um porto seguro, antes do regresso final à sonhada Ítaca, ${ }^{36}$ onde uma Penélope o aguardaria.

\footnotetext{
${ }^{34}$ Uma das muitas imagens andresenianas da interpenetração destes diferentes estratos é a belíssima imagem dos deuses como "sol interior das coisas" (cf. o poema "O crepúsculo dos deuses", Obra poética, p. 556).
}

${ }^{35}$ A ilha de Tasos, a par de Egina, é celebrada por Sophia no poema intitulado "Não te esqueças nunca" (Obra poética, p. 764): "Não te esqueças nunca de Thasos nem de Egina/ O pinhal a coluna a veemência divina/ O templo o teatro o rolar de uma pinha/ $\mathrm{O}$ ar cheirava a mel e a pedra a resina/ Na estátua morava tua nudez marinha/ Sob o sol azul e a veemência divina/ Não esqueças nunca Treblinka e Hiroshima/ O horror o terror a suprema ignomínia". Claramente este poema retrata as duas ilhas gregas como paradigmas da beleza perfeita e intocada da natureza, em harmoniosa síntese com a cultura, por contraste com as marcas mais representativas da violência e capacidade de destruição do homem. Estes são dois aspectos contrastantes da realidade da vida e do mundo que nos cerca. Mais uma vez harmonia e caos se contrapõem.

${ }^{36}$ Sophia dedica a Ítaca dois poemas ("Ítaca", "O rei de Ítaca", Obra poética, p. 559 e 681, respectivamente). Sobretudo o primeiro parece essencial para a simbologia por ela atribuída à ilha de Ulisses: "Estarás perdida no interior da noite no respirar do mar/ Porque esta é a vigília de um segundo nascimento/ $\mathrm{O}$ sol rente ao mar te acordará no intenso azul/ Subirás devagar como os ressuscitados/ Terás recuperado o teu selo a tua sabedoria inicial/ Emergirás confirmada e reunida/ Espantada e jovem como as estátuas arcaicas". Recordando a experiência da navegação de Brindisi para Ítaca, Sophia vê 


\section{Conclusões}

Se as viagens à Grécia se revestiram de grande intensidade para Sophia, não a fizeram, contudo, inflectir na sua trajectória poética, antes representaram uma superlativação de experiências e da sua expressão estética. Limpidez, harmonia, plenitude, centrais para o seu sentir e dizer o mundo, são agora vividas de modo absoluto.

$\mathrm{Na}$ Grécia com que Sophia se defronta nos dois poemas analisados, convergem, como elementos estruturantes, a dimensão física e a cultural. Haverá, em primeiro lugar, a notar que não se trata de uma geografia grega qualquer, mas das ilhas do Egeu, onde a marca da luminosidade mediterrânica é mais radical. De acordo com o testemunho da própria Sophia, a sua reacção num primeiro encontro com o continente grego, ao aportar no Golfo de Corinto, foi a de dar graças por ter nascido, no reconhecimento de que aquela experiência de beleza absoluta the proporcionou a dimensão "religiosa" do belo e da unidade: "Há um instante em que o regozijo em frente da beleza do Universo une, une todas as coisas e o que é poético é também religioso" (PASSOS, 1982, p. $3)$. Neste testemunho revive a ideia profundamente helénica de que aos mortais são consentidos instantes de comunhão com os deuses na vivência da perfeição essencial. Se a physis sobrevive ao desgaste do tempo e se oferece num quase eterno esplendor, a cultura, fragmentada pelo curso dos milénios, necessita da imaginação poética para se recompor.

Tendo a poeta percorrido diversos espaços da Grécia (Atenas, Delfos, Corinto, Epidauro e Olímpia), não é certamente por acaso que os poemas de evocação a Pessoa arranquem de uma vivência insular. Cremos residir aqui, na experiência desta physis grega, repartida e luminosa, um dos grandes impulsos para a evocação do poeta - devendo registar-se que o poema "Cíclades" se encontra integrado num ciclo a que Sophia deu o significativo nome de "Arquipélago". A imagem da divisão faz emergir, por associação, a da heteronímia, enquanto o excesso de luz e de real acarreta, por oposição, a exploração das díades luz/sombra e

na famosa ilha do mar Iónio uma espécie de reduto eutópico, onde poderá recuperar "a sabedoria inicial" e a perdida "unidade". 
presença/ausência, que, constituindo dois temas profundos de Sophia desde o seu primeiro livro (ROSA, 1987, p. 15-20), são aqui exploradas por referência ao poeta de discreta vida e multíplice identidade.

Qual a imagem de Pessoa que ressalta de ambos os textos? Podemos dizer que há traços fundamentais que lhes são comuns - Pessoa como ausência, Pessoa como navegante e Pessoa como dividido -, os quais, no seu conjunto, colaboram num retrato coerente. A personalidade assim evocada, tão contrária à de Sophia, impõe-se-lhe como enigma a decifrar. ${ }^{37} \mathrm{O}$ fascínio sobre ela exercido por um absoluto tão diferente de si mesma justifica que retorne ao tema num segundo retrato-diálogo, em que o perfil do poeta dos heterónimos é aliás traçado por recurso aos mesmos tópicos. Comum aos dois poemas é igualmente a convocação de Pessoa à Grécia, imaginando-lhe um percurso e uma vivência distintos daqueles que o caracterizaram.

No entanto, uma diferença se torna evidente: enquanto no poema "Em Hydra" era o ambiente de plenitude luminosa que fazia emergir a imagem de um Pessoa sombra/ausência, em “Cíclades” o contexto grego cede lugar a uma evocação do poeta no seu quotidiano lisboeta. Esse recuo das ilhas gregas como cenário, em vantagem para a penumbra dos cafés lisboetas por onde Pessoa peregrinava, justifica que Ulisses, o navegante de muitos portos e de muitas ilhas, uma espécie de paradigma de fragmentação, esteja igualmente omisso no segundo poema.

Persistente é a interacção enigmática entre os dois poetas, ao mesmo tempo controversa, porque fundada em sensibilidades muito diversas, mas responsável por um fascínio que inevitavelmente atrai polos opostos. Seduzida ela mesma pela luminosidade esplendorosa do mundo grego, aberta à pujança, geográfica e cultural, deste universo que

\footnotetext{
${ }^{37} \mathrm{Na}$ já referida entrevista a Maria Armanda Passos, Sophia revela (p. 5): “Os primeiros poemas sobre Fernando Pessoa tiveram como ponto de partida o terem-me pedido uma conferência sobre ele. Ia ficando meio louca porque escrever em estilo lógico e explicativo é contrário à minha organização natural. No fim da conferência acabei mesmo um pouco alucinada, porque li o Pessoa todo ao mesmo tempo e acabei por ouvir fisicamente as quatro vozes do Fernando Pessoa. Fiquei completamente cercada. E, dessa espécie de cerco, de insatisfação e de incapacidade de decifrar o Fernando Pessoa logicamente, nasceram os poemas. É-me um pouco difícil explicar”.
} 
agora lhe proporciona fortes sensações, Sophia é levada a reconhecer a diferença que a separa de um Pessoa sempre admirado. Mas não é censura o que lhe domina o pensamento, antes uma espécie de carinho maternal, de apelo afectivo perante alguém tão intimamente dotado para usufruir de tão absoluta e primaz plenitude.

\section{Referências}

\section{Edições}

ANDRESEN, S. M. B. Antologia. Edição aumentada, com prefácio de Eduardo Lourenço. Lisboa: Moraes Editores, 1975.

ANDRESEN, S. M. B. Dia do mar. Lisboa: Edições Ática, 1974.

ANDRESEN, S. M. B. Obra poética. Editado por Carlos Mendes de Sousa. Lisboa: Assírio \& Alvim, 2015.

ANDRESEN, S. M. B. Poesia I. Coimbra: Edição da Autora, 1944.

\section{Estudos}

ANDRESEN, M. Revelação de um espólio. Jornal das Letras, Oeiras, n. 1052, p. 7, jan/fev. 2011. Entrevista.

CECCUCCI, P. Trazer o real para a luz: o olhar e o ouvido voltado para os seres e as coisas na poética de Sophia. Revista Colóquio/Letras, Lisboa, n. 176, p. 15-27 jan./jun. 2011.

COELHO, A. L. No mundo de Sophia. Público, Lisboa, 21 jun. 2009. Caderno P2, p. 4-7.

COELHO, E. P. O real, a aliança e o excesso na poesia de Sophia de Mello Breyner Andresen. In:

Portucalense: 1972. p. 225-250. . A palavra sobre a palavra. Porto:

COELHO, E. P. Sophia, a lírica e a lógica. Revista Colóquio/Letras, Lisboa, n. 57, p. 20-35, 1980.

HÖRSTER, M. A. Para uma história da recepção de Rainer Maria Rilke em Portugal (1920-1960). Lisboa: FCB/FCT/MCT, 2001. 
LANCIANI, G. Sophia de Mello Breyner Andresen: o labirinto da palavra. Revista Colóquio/Letras, Lisboa, n. 176, p. 9-14, 2011.

LOURENÇO, E. Para um retrato de Sophia. In: ANDRESEN, S. M. B. Antologia, I-VII. Lisboa: Moraes Editora, 1978.

MARTINHO, F. J. B. Sophia lê Pessoa. Persona, Porto, n. 7, p. 26-29, 1982.

MOURA, A. Sophia de Mello Breyner Andresen fala-nos de poesia e de arte. Diário Popular, v. 25, n. 4, p. 5, 1957

MOURÃO-FERREIRA, D. Sophia de Mello Breyner Andresen. Na publicação de No tempo dividido. In: .Vinte poetas contemporâneos. 2. ed. revista e ampliada. Lisboa: Ática, 1980. p. 173-177.

NUNES, M. L. Vida de versos. Jornal das Letras, Oeiras, n. 1052, p. 6-7, jan.-fev. 2011.

PASSOS, M. A. Sophia de Mello Breyner Andresen: "Escrevemos poesia para não nos afogarmos no cais...". Jornal das Letras, Oeiras, n. 26, p. 2-5, 16 fev. 1982.

ROSA, A. R. A presença e a ausência em Sophia de Mello Breyner Andresen. In: . Incisões oblíquas: estudos sobre poesia portuguesa contemporânea. Lisboa: Caminho: 1987. p. 15-20.

TOMÉ, L. F. Sofia de Mello Breyner termina o livro de poesia "estilo manuelino". Diário de Notícias, n. VI-VII, 20 dez. 1987. Caderno Cultura. 